\title{
Twenty-five years of APSE: The Association of People Supporting EmploymentFirst
}

APSE has played a most critical role in establishing supported employment as the viable rehabilitative service for individuals with significant disabilities who have been unable to become employed in the workforce. In the late 1980s and early 1990s the U.S. Department of Education offered major federal grants to over 40 states in order to promote the implementation of supported employment. These projects were, for the most part, quite successful, but they did not last long enough and the lack of sustainability affected the speed of implementation of supported employment. Fortunately, about then APSE was born and began to take on a national leadership role in the states and at the federal level. APSE has state chapters with conferences and a national conference annually, it has a voice at the national advocacy table, it promotes newsletter briefs and members receive the Journal of Vocational Rehabilitation, an international journal. APSE has helped lead the way for international implementation of supported employment. In Dublin this June, will be the 20th meeting of the European Union of Supported Employment.

Supported employment (SE) emphasizes the benefits of having opportunities for real, integrated work as the first choice of persons with significant disabilities. All parties involved benefit from competitive employment. Such employment provides the individual with a disability a real job, benefits, and the dignity that arises from gainful employment.

With SE, the employer gets a good employee and receives specialized support for job acquisition and retention. The family is able to see the newly employed family member in a fully competent role in the workplace. Finally, taxpayers spend less money than they would to support the individual in a segregated day program. However, several questions remain: Why do the vast majority of individuals with intellectual, physical, psychiatric, and sensory disabilities remain in segregated day treatment programs? What values are service providers and advocates operating under?

The answers to these questions lie partially in the inability of advocates and people with disabilities to adequately coordinate their collective efforts to increase employment opportunities. Adult service systems using segregated services remain deeply entrenched as they have for decades. Changing this way of providing services is extremely difficult, particularly in times of reduced funding resulting from a recessionary economy. Hence, there is an overwhelming necessity to market the positive attributes of SE intended to serve people with significant disabilities.

For 25 years, APSE has stood for: Presumption of employment, person-centered control, wages, supports, interdependence, and social connections within the community. These are the underlying values that should be reflected in any quality employment program or organization for people with significant disabilities. It is only with a clear vision and an articulated set of core values that individual organizational members are able to consistently make decisions and conduct business in a manner that 'over time' stays true to the mission of the organization. 
It is clear to most that with full inclusion occurring more and more in the schools, and the US Department of Justice settlements in many states looking to implement the Olmstead decision, that supported employment continues more than ever to be the "go-to" service for transition specialists, consumers, families and adult providers. Medicaid waiver dollars are widely used now for supported employment. None of this would be happening without the advocacy and leadership of APSE leaders and membership.

With the help of our formidable Executive Director, Dr. Laura Owens, we have been able to pull together a number of quotes and testimonials to APSE, many of who have been pioneers of supported employment for over three decades.

This will be a great 25th year anniversary!

Enjoy the comments that follow!

Paul Wehman, Ph.D. Editor, JVR

At APSE, the goal is prosperity; not something that is better than nothing.

\section{Jon (Alex) Alexander \\ Kaposia \\ Minnesota}

APSE Board President, 2011-2012

APSE's consistent message over the past 25 years is that people with disabilities are a vital part of the workforce and can - in fact should - work alongside people without disabilities earning the same wages and benefits. As with all civil rights issues, equal but different is not equal.

\section{Debbie Ball SoCal APSE California}

My APSE membership provides me with a valuable opportunity to surround myself with like-minded people that "get-it." As an organizational leader APSE helps me stay on top of emerging employment issues that help our organization be relevant and responsive to a rapidly changing environment. The camaraderie and lively discussions with other APSE members inspire me and continually shape my clarity of mission.

\section{Sherry O. Becker NIVC Services}

Employment for ONE, Employment for ALL

Pleased to announce, the Association of People Supporting EmploymentFirst - it's the 25th year! People with disabilities will be employed in their communities, in careers they make clear.

APSE, 3,000 members strong advocate, network and train to ensure equality and not just a label. What an accomplishment for this grass roots organization that started out at a kitchen table.

People with disabilities, employed in meaningful careers and contributing community members those archaic services will soon be eliminated, part of the past and be nothing but embers.

EmploymentFirst is THE option, the first and preferred and we will accept nothing less.

We have come too far, accomplished too much there will be no regress!

\section{Macey Chovaz Creative Employment Opportunities, Inc. Wisconsin}

APSE has meant a lot to me and others who have struggled to battle the bigotry of low expectations of people with disabilities. For over 25 years, the organization promoted training, new techniques, and provided a conference as a forum and more importantly, a place to meet others who share your view of what social inclusion really means. Some of these colleagues have become my good friends - it means a lot to hear a friendly voice in our always difficult struggle to move an entrenched system of segregation. APSE is my village. A place where we can argue about the path, but not the goal.

Dale DiLeo

TRN

Florida

APSE Board President, 1998-1999

APSE seized the moment 25 years ago when its founders, Wendy Wood and Mark Hill, recognized that demonstration projects at the University of Oregon and Virginia Commonwealth University proved that individuals with the most significant disabilities could work in the general workforce. Wendy and Mark also understood that successful employment would rely upon the job seeker being the focal point throughout the employment process and that those who provided employment 
services to them would require a set of highly specialized competencies. Twenty-five years later, APSE remains true to its organizing principles and mission. APSE is a national and state leader in advocating for employment of individuals with disabilities and provides an important venue for advocacy, policy development, dialogue, and staff development. Personally, APSE has been a catalyst for my own career development. I will always remain grateful to Wendy and Mark for asking me to be part of their early efforts to build the organization. I am proud to identify myself as an APSE member and look forward to celebrating its silver anniversary along with my colleagues and friends around the country.

\section{Karen Flippo Institute for Community Inclusion Rhode Island}

APSE has been the north star for myself and many individuals and organizations. It has been the place where people are grounded in values and a strong inclusive philosophy. APSE has provided the direction to create possibilities. For over 25 years, this organization has provided a forum for people to gather together to discuss, disagree, and create new ideas with people with disabilities and employers. It is the only organization with a sole focus on employment for people with disabilities.

\section{Teresa Grossi, Ph.D. Indiana Institute on Disability and Community Indiana} APSE Board President, 2007-2008

Being an active member of APSE in both my state and nationally has helped to empower me to become more proactive in my role as advocator for my students. APSE has shown me that anyone, no matter their disability, has abilities to work, that they have wants and dreams to have a job and career just like you and I, and they want and need to be contributing members of their families and society.

\section{Pat Gutowski} New Jersey

Since its inception, APSE has stood for a very clear cause - that people with disabilities have the right to fully participate in the workforce just like everyone else. Within these efforts, APSE has recognized that having a job is not just a means to a paycheck - it's a way to become part of a community, to connect with others, to learn, to build friendships, to grow as a person. APSE has done the same for me. I first became a member of APSE in 1991, when APSE was just three years old, and I was a newly minted job coach. We've grown up together, and it's been a wonderful journey. I have learned and grown so much through APSE, and have met so many wonderful, committed (and yes, fun!) people. Most importantly, APSE has allowed me to join with others in a common cause for the civil rights of people with disabilities to be treated with dignity and respect as fellow citizens, fully included in all aspects of society. I am so proud and humbled to be President of this wonderful organization on its 25th anniversary. Congratulations to APSE and thank you - thank you to all the members, staff, and volunteers who blazed the trail and made the organization what it is today - and thank you to those who will guide us into a future where it is simply a given that people with all types of disabilities are employed, pursuing careers, and building assets just like people without disabilities.

\section{David Hoff \\ Institute for Community Inclusion Massachusetts APSE Board President, 2012-Present}

Since APSE began, Employment Support Professionals (job coaches) have been the back bone of supported and customized employment. Yet a 2013 CNN Money.com survey listed the job of a job coach as one of the highest stress - low wage careers in America! Bravo to APSE for developing the national Certificated Employment Support Professional (CESP) credential! The CESP credential defines national competency standards that, in time, will raise salaries for ESPs across the nation, earning them the respect and career status they so richly deserve.

\section{Patricia K. Keul \\ Employment Support Professional Certification Council (ESPCC) North Carolina}

In a national landscape harboring low expectations about the employment capacities of Americans with significant disabilities, National APSE has been a consistent beacon of light, challenging erroneous assumptions and promoting this simple idea - "integrated employment at market rate wages in the competitive labor force is accessible to anyone when 
jobs are developed, and sometimes customized, to match the interests, skills, and support needs of individuals one job seeker at a time."

\section{Don Lavin \\ Strengths At Work \\ Minnesota}

Through the years APSE's advocacy work has had a significant impact on implementing the ADA's mandate for people to be served in integrated employment settings. It has been a force for positive change throughout the individual states and the nation and has become an important component within the larger disability rights movement. It is my hope that we will continue to fight for the presently unrealized dream of so many: to have a real job, for equal pay, and with positive enhancement of the social network that many of us experience through our work.

\section{Robert (Bob) A. Lawhead Community Link Colorado} APSE Board President, 1997-1998

\section{APSE}

Two and a half decades...

Welcoming space for honest discussion about decent jobs for people with disabilities.

Welcoming space for leaders in any role.

Small and fragile at the start - now national and international in scope and influence.

Remembering it always is 'one person at a time'.

Relentless in pursuit of economic equality.

David Mank, Ph.D. Indiana Institute on Disability and Community Indiana

APSE inspired a whole generation of leaders who have altered the landscape in the employment of people with disabilities throughout the world. I look forward to a new generation of leaders that will help improve the lives of people with disabilities, to live, work and enjoy life in their communities. I am proud to have been a part of creating that legacy.

Bob Niemiec

Minnesota

APSE President, 2002-2004

APSE is more than an organization. It's like an extended family. The annual conferences were often the only real training I received each year. The line-up of All-Stars, or the-best-of-the-best in the field, always amazed me. APSE also exposed me to amazing people of all walks of life and gave me added respect for people with a variety of challenges - but more importantly people with a host of gifts! As a presenter APSE played a major role in my development and as a source of referrals. I will also say having served on the Board of Directors, APSE is an active and vibrant organization. They are always looking to stay relevant, on the cutting edge, and serve their community.

George Nostrand Vermont Psychiatric Survivors (VPS) Vermont

In 1991, I left my teaching position to begin a new venture - starting an employment agency for individuals with disabilities - Creative Employment Opportunities, Inc. (CEO). CEO began out of a vision to advance economic solutions to business through the social inclusion of all people. I felt isolated in my vision until I attended my first of many APSE conferences in Denver, Colorado in the summer of 1991. The rest is history! I quickly became actively involved in the organization, starting the Wisconsin APSE chapter, becoming a National Delegate, serving as a National Board member, and now I have the honor of being the fourth Executive Director. Thank you to all of those who came before me with the vision of integrated employment for all individuals. I have come full circle with APSE and am excited about the next 25 years!

Laura A. Owens, Ph.D. Executive Director, APSE 2008-present

APSE has been the leader in the nation on disability employment advocacy and policy. During its 25 year history, APSE has always maintained its values and mission to promote integrated competitive employment for individuals with disabilities. It is also the only organization focused on elevating the professionalism and career development of job coaches and other employment support personnel. I am proud to have been a part of the APSE family all these years, witnessing its tremendous growth and remarkable accomplishments. Good luck APSE on the next 25!

Wendy Parent-Johnson, Ph.D. South Dakota Center for Disabilities South Dakota 
As an employee in a sheltered work program back in the early 80's, I knew that there was something more the people I served could do. Around that time, I was introduced to supported employment and social role valorization and it all made so much sense. As I became more comfortable with the strategies and attitudes inherent in supported employment and less comfortable with what I saw happening day to day, I began reaching out to others to learn more and for support. When I found APSE in the late 80's, I finally had people to talk with who shared the values of inclusion and employment. That support sustained me when funders and other providers said it was impossible. Along with some great staff, I began supported employment programs at two agencies... and APSE kept me going.

APSE has been the source of my education. I have learned so much from the pioneers, David Mank, Paul Wehman, Wendy Wood, Suzie Hutchison, Dale Dileo, and so many more....all at APSE conferences and events. As a result, my agency and I are better at providing employment support and more aware of how we can continually improve. It is hard to believe it has been 25 years (cause that makes me really old). APSE's accomplishments are many but the most important, hundreds of thousands of people who have community jobs. APSE's commitment, values, and services are stronger than ever and will continue to have that kind of impact far into the future.

\section{Susan Rinne LifeDesigns Indiana APSE Vice President, 2012-present}

Having been involved in APSE since its inception, it is hard to believe that a quarter century has passed. I feel very fortunate to have been closely involved in the critical work of this organization as we advance the basic right of all individuals to integrated employment and full citizenship. Although incredible strides have been made toward this goal, much work remains. Thank you to all APSE members whose tireless efforts continue to change lives every day. Onward!

Patricia Rogan, Ph.D. Indiana University Purdue University Indianapolis Indiana APSE Board President, 2000-2002
APSE's mission statement is that, "Through advocacy and education, APSE advances employment and self-sufficiency for all people with disabilities." This simple, yet unequivocal statement demonstrates the power of APSE and its membership, because APSE believes that all people with disabilities are capable of employment and are entitled to a life of selfsufficiency.

For the past 25 years, APSE has stood for nothing less than the complete inclusion of people with disabilities. APSE's elegant but profound belief that every person with a disability should be afforded the opportunity to work, is founded in the quintessential American belief that every human being is entitled to life, liberty and the pursuit of happiness.

For over a decade, I have had the pleasure of working in conjunction with APSE, and have had the honor of meeting with many of its leaders and members, and in every meeting I have been inspired by their unflagging commitment to the inherent value of people with disabilities in the workplace, in the marketplace and in our society.

APSE both understands and believes that no society can truly move forward, unless it moves forward with all of its members. History proves that when marginalized member of our society have been given the opportunity to achieve their full potential, every member of our society of our benefits.

Congratulations on 25 wonderful years of service to people with disabilities, and to America...

\section{Neil Romano \\ Maryland Former Assistant Secretary of ODEP}

I'm so excited to hear about APSE celebrating 25 years!!! When APSE was conceived all those years ago, I had no imaginings of that fledging association achieving such a landmark. Supported employment is a successful approach to help individuals with disabilities achieve real work in their communities. With work, comes the recognition that people with disabilities are participants and contributors, co-workers and neighbors. Because of this success, people involved in supported employment have an enthusiasm and energy 
about their work that folks in other fields envy. APSE is such a wonderful gathering place for that energy and enthusiasm to advance improvements in practice and to shape policy in Washington. I'm so proud to have played a role in founding APSE. Congratulations to you all!!

Wendy M. Wood Founding Executive Director, 1988-1994 